\title{
AVIAN RESPONSE TO LANDSCAPE CHANGE IN FRAGMENTED SOUTHERN GREAT PLAINS GRASSLANDS
}

\author{
Bryan R. Coppedge, ${ }^{1,2}$ David M. Engle, ${ }^{1,2}$ Ronald E. Masters, ${ }^{3}$ And Mark S. Gregory ${ }^{2}$ \\ ${ }^{1}$ Rangeland Ecology and Management, Oklahoma State University, Stillwater, Oklahoma 74078 USA \\ ${ }^{2}$ Department of Plant and Soil Sciences, Oklahoma State University, Stillwater, Oklahoma 74078 USA \\ ${ }^{3}$ Department of Forestry, Oklahoma State University, Stillwater, Oklahoma 74078 USA
}

\begin{abstract}
We examined the dynamics of avian communities associated with fragmented grasslands in Oklahoma, USA, using long-term (1965-1995) raw (stop-level) data from the Breeding Bird Survey (BBS). Aerial photography was used to document changes in land cover type and landscape pattern as affected by woody plant (mostly Juniperus virginiana L.) encroachment and concurrent cropland conversions to agricultural grassland under the Conservation Reserve Program (CRP). Rank trend analysis identified species with significant population trends, and canonical correspondence analysis (CCA) was used to identify important environmental gradients from a group of descriptive habitat variables that included land cover type composition and indices of vegetation cover, landscape pattern, and grassland patch structure.

Avian community structure shifted along gradients of increasing woody plant cover and indicators of continuing landscape fragmentation. Open-habitat generalists, woodland, and successional scrub species generally increased, whereas many grassland species decreased. In some instances, neotropical migrants responded positively to increasing woody vegetation. Some grassland birds also showed a positive response to increases in agricultural grassland, but only in areas of severe juniper encroachment. Most grassland species exhibited consistent declines related to the influx of woody vegetation and associated landscape changes.

Woody plant encroachment into southern Great Plains grasslands already fragmented by agricultural activity represents a conservation management dilemma. Although woody vegetation in remnant native prairies may provide habitat for some declining neotropical migrants that require shrubby areas, grassland structure and suitability is compromised for many declining grassland-endemic birds. Cropland conversion to agricultural grassland does appear to provide suitable habitat for some grassland species. However, this benefit appears to be limited to areas where woody plant invasion into grasslands is relatively advanced, and may have only a temporary effect, as most CRP areas are likely to return to agricultural production in the near future. Changes are needed in grassland management practices to restrict woody plant encroachment and fragmentation; otherwise, continued declines in grassland bird populations can be expected.
\end{abstract}

Key words: agriculture; Breeding Bird Survey; canonical correspondence analysis; Conservation Reserve Program; fragmentation; grassland birds; Great Plains; juniper; landscape structure; Oklahoma (USA).

\section{INTRODUCTION}

Disruption of ecosystem processes that accompany human activity can have substantial effects on regional physiognomy (Saunders et al. 1991, Robinson et al. 1992). For example, agriculture and settlement in the Great Plains have converted once-open grasslands into a mosaic of cultivated croplands, prairie remnants, and expanding woodlands (Johnson 1994, Samson and Knopf 1994). Although fire historically restricted woody plant abundance and maintained plains grasslands (Bragg and Hulbert 1976, Axelrod 1985), juniper (Juniperus spp.) and mesquite (Prosopis spp.) woodlands are rapidly expanding in many grasslands in the absence of fire (Archer 1994). Other regional and glob-

Manuscript received 15 July 1999; revised 17 December 1999; accepted 6 January 2000; final version received 4 February 2000. al human activities may also be contributing to woody plant increases. Junipers and other evergreen species are actively planted as windbreaks and shelterbelts (Atkinson 1985), and various forms of exotic woody vegetation accompany and escape from human settlements (Blair 1996). Intense or continuous cattle grazing removes herbaceous biomass, which reduces competition for woody seedlings and eliminates the fuel needed for fire (Brown and Archer 1989, Engle et al. 1995). Cattle may also contribute to woody plant abundance as seed dispersers (Brown and Carter 1998). Furthermore, global increases in atmospheric $\mathrm{CO}_{2}$ levels may also favor the growth of $\mathrm{C}_{3}$ woody plants over $\mathrm{C}_{4}$ grasses (Polley et al. 1994).

Human impact has been so substantial that grasslands are now considered among the most endangered ecosystems in North America (Samson and Knopf 
1994). Populations of many species dependent on grassland habitats have decreased, and precipitous declines have occurred in endemic avian diversity and abundance (Askins 1993, Knopf 1994). Fortunately, widespread interest in soil, grassland, and wildlife conservation led to the creation of the Conservation Reserve Program (CRP) in 1985. The CRP is a federal subsidy promoting the removal of marginally productive or highly erodable cropland from annual cultivation and into perennial vegetative cover (Young and Osborn 1990). Although it is a nationwide program, nearly half of the cropland removed from cultivation by the CRP is in the Great Plains (Soil and Water Conservation Society 1994).

The purpose of our study was to examine avian community responses to dual landscape changes in Oklahoma, United States, associated with extensive juniper (Juniper virginianus) invasion into native grassland remnants (Engle et al. 1995) and the conversion of cropland by the CRP. Numerous studies have demonstrated the importance of landscape pattern on habitat suitability and use for birds in forested (Hansen and Urban 1992, McGarigal and McComb 1995, Flather and Sauer 1996) and shrubsteppe habitats (Wiens and Rotenberry 1981, Wiens et al. 1987). Only recently have studies begun to directly focus on landscape patterns in remnant grasslands and their effects on the endemic avifauna (Herkert 1994, Helzer and Jelinski 1999). However, no study has addressed the effects of encroaching woody vegetation on grassland birds over a significant length of time. Although recent studies have compared the relative importance of vegetation composition, structure, and landscape pattern to avian communities (Pearson 1993, Farina 1997, Saab 1999), these relationships have not been examined for breeding birds in North American grasslands.

\section{Methods \\ Study areas}

The availability of long-term avian population data prompted us to choose landscapes surrounding Breeding Bird Survey (BBS) routes as study areas. The BBS is an annual avian survey conducted in late May through June (Bystrak 1981) at $>3000$ sites across North America (Droege 1990). During a survey, a skilled observer conducts 503 -min point counts at 0.8 $\mathrm{km}$ intervals (or stops) along a permanent 39.4-km route, recording all birds seen or heard in a $0.4 \mathrm{~km}$ radius. Three routes located near Alva, Oklahoma (Fig. 1) were chosen because of their close proximity, the quality and consistency of BBS data, and their location in or near areas of expanding juniper populations (Engle et al. 1995). Hereafter referred to by their BBS designations as the Eagle City (OK BBS route number 19 ), Tegarden (OK BBS route number 30), and Lookout (OK BBS route number 31 ) study areas, the routes lie in a region of mixed-grass prairie with a continental

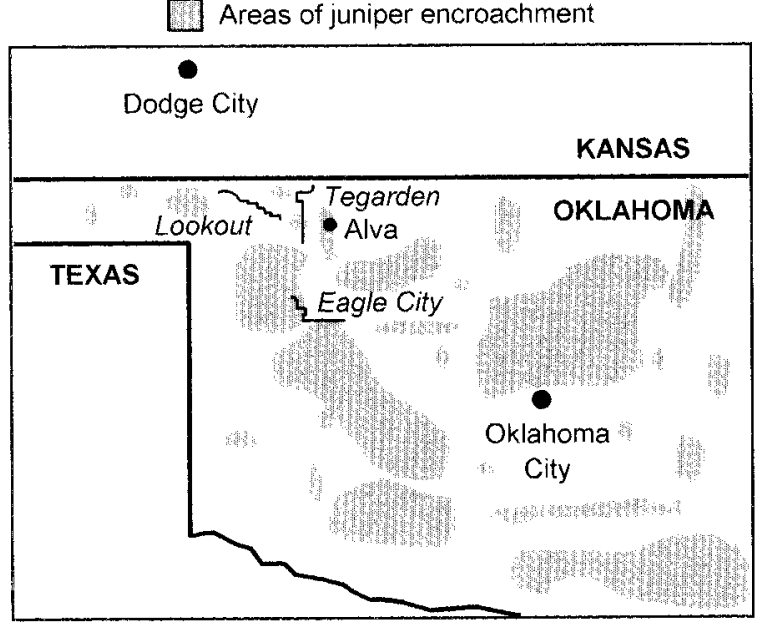

FIG. 1. BBS study route locations in northwestern Oklahoma. Shaded areas represent significant juniper encroachment locations within the state (adapted from Engle et al. 1995).

to subhumid climate, mean annual temperature of $19^{\circ}$ $\mathrm{C}$, and mean annual precipitation of $88 \mathrm{~cm}$. Regional agriculture is mostly wheat (Triticum aestivum) and cattle (Bos spp.) production, with cropland enrollments into the CRP beginning in 1985. Most of the CRP plantings in Oklahoma were monocultures of exotic pasture and forage grasses such as old-world bluestems $A n$ dropogon spp., or lovegrasses Eragrostis spp.(Newman 1988).

\section{GIS database development}

We used black-and-white aerial photography to assess landscape changes in relation to agricultural practices and juniper encroachment. To distinguish evergreen juniper from deciduous vegetation, we used 61 $\times 61 \mathrm{~cm}$ enlargements at a 1:7,920 scale taken in October 1965, November 1981, and February 1995. We designated the $0.8 \mathrm{~km}$ diameter area surveyed at each stop on the BBS route $(n=50)$ as a replicate landscape (Fig. 2), and portions of photography covering these 50-ha areas were delineated on acetate overlays.

Photointerpretation used a classification scheme based on land cover type (Dunn et al. 1991), with two levels of data assignment. All polygons (landscape patches) were manually delineated on the acetate and were classified into one of 11 general land cover types. These cover types were of two general categories: areas of natural vegetation or areas of anthropogenic and miscellaneous land cover (Table 1). Polygons with natural vegetation cover were further assigned canopy cover class values for each of four vegetation components (Daubenmire 1959): juniper tree cover, deciduous tree cover, shrub cover, and herbaceous cover. All classifications of land cover type and assignments of vegetation cover class were ground-truthed on the 1995 photography. Following interpretation, images were 


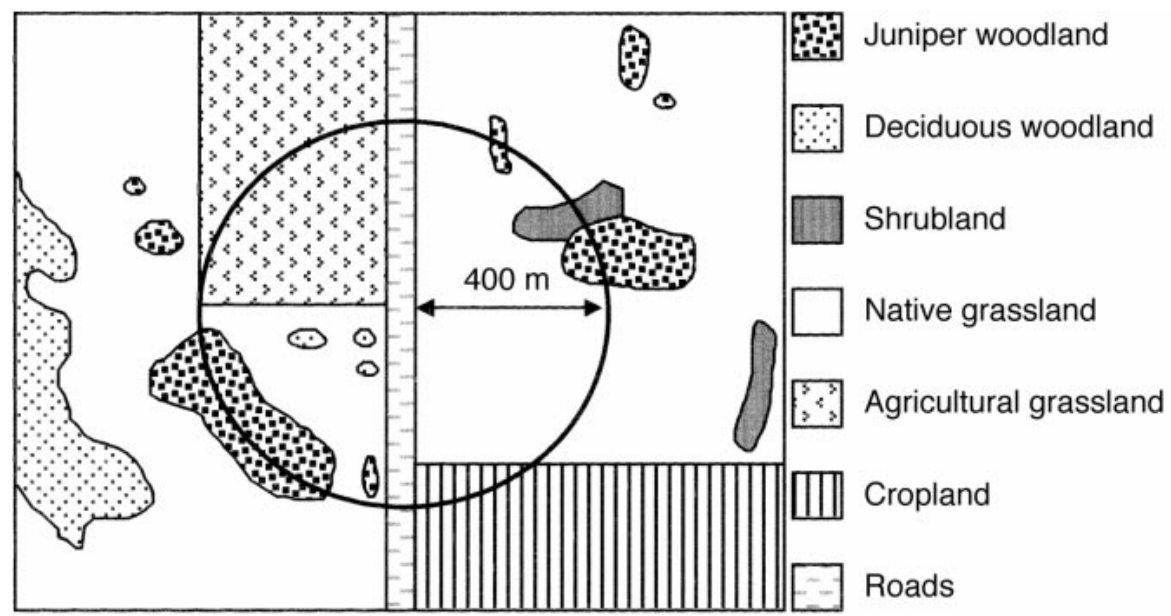

FIG. 2. Illustrative diagram of a BBS stop and the $0.4 \mathrm{~km}$ radius survey area used as a replicate landscape to examine bird response to landscape change from 1965 to 1995.

digitized, imported to a geographic information system, and geo-registered.

\section{Landscape database}

We calculated the relative composition of the 11 land cover types for each landscape. An area-weighted cover index for each of the four vegetation types was derived for each landscape as:

$$
\sum_{i=1-j}^{j} P_{i} C_{i k}
$$

where $P_{i}$ is the relative proportion of the landscape area composed of polygon $i$; and $C_{i k}$ is the cover class value midpoint (percentage) for vegetation type $k$ in polygon $i$. A fifth vegetation index, total tree cover, was also calculated by summing the juniper and deciduous tree cover indices. These indices were designed to document the relative amounts of particular vegetation types in the landscapes, and how the presence of this vegetation might influence bird abundance.

Landscape pattern analysis was performed on the landscapes with FRAGSTATS version 2.0 (McGarigal and Marks 1995). Numerous indices of landscape pattern are available, but many are highly correlated, and no consensus exists as to which indices may best describe any particular ecological phenomena (Gustafson 1998). We followed recent recommendations to use separate, more intuitive indices of landscape pattern (Davidson 1998). Two widely used spatial configuration indices included were mean patch size and mean patch core size. Patch size is a traditional measure of landscape structure that has been shown to affect several measures of biotic persistence and dynamics in fragmented landscapes (Robinson et al. 1992). A patch core is the portion of a landscape patch that is a specified distance away from the patch edge, a measure that would instinctively be associated with the persistence and dynamics of area-sensitive species (Gustafson
1998). For this study, we applied a 100-m buffer on all patch boundaries to derive a core area (McGarigal and McComb 1995).

We also tabulated the total number of landscape patches and total patch edge. Both of these indices measure the degree of habitat fragmentation and heterogeneity (McGarigal and Marks 1995). Landscape diversity indices quantify landscape composition, and are based on both patch type richness and evenness. An evenness index measures the relative distribution of area among patch types. Shannon's diversity and evenness indices were used for this study because of their usefulness in making relative landscape comparisons (McGarigal and Marks 1995).

The patch interspersion/juxtaposition index measures the adjacency and distribution of patch types within the landscape. This index is calculated as a percentage of maximum patch type adjacencies for a given number of patch types. When examined collectively, this group of landscape metrics (Table 1) provided a comprehensive guide to changes in overall landscape structure (Davidson 1998). Because many of these measures can also be applied to specific patch types (McGarigal and Marks 1995), we also examined the total number, mean patch and core size, and interspersion/juxtaposition of native grassland patches within each landscape to examine grassland structural changes and properties and their potential influence on avian abundance.

\section{Avian populations trends}

Rank trend analysis was used to identify species with significant population changes in each study area (Titus et al. 1990). This method detects only the direction of the population trend, not the magnitude of change (Thomas 1996), and is appropriate for analyzing disjunct groups of annual count data (Titus et al. 1990). The technique has advantages over more widely used 
TABLE 1. Variables used to assess avian response to landscape dynamics in three Oklahoma mixed-grass prairie study areas.

\begin{tabular}{|c|c|}
\hline Variable (units) & Description \\
\hline \multicolumn{2}{|c|}{ Land cover types (percentage composition) } \\
\hline \multicolumn{2}{|c|}{ Natural vegetation land cover types } \\
\hline Juniper woodland & Wooded areas with juniper canopy cover $>60 \%$. \\
\hline Mixed woodland & $\begin{array}{l}\text { Wooded areas with deciduous and juniper composition about } \\
\text { equal; combined canopy cover }>60 \% \text {. }\end{array}$ \\
\hline Deciduous woodland & Wooded areas with deciduous canopy cover $>60 \%$. \\
\hline Shrubland & $\begin{array}{l}\text { Vegetated areas with }>50 \% \text { shrub (low-statured perennial } \\
\text { woody plants) canopy cover. }\end{array}$ \\
\hline Native grassland & $\begin{array}{l}\text { Native perennial mixed-grass prairie with }>50 \% \text { grass cano- } \\
\text { py cover. }\end{array}$ \\
\hline \multicolumn{2}{|c|}{ Anthropogenic/miscellaneous land cover types } \\
\hline Agricultural grassland & $\begin{array}{l}\text { Areas with }>50 \% \text { seeded grass canopy cover (monocul- } \\
\text { tures) of non-native species. Used for livestock grazing or } \\
\text { hay meadows. Most are CRP cropland enrollments. }\end{array}$ \\
\hline Cropland & Cropland areas cultivated annually. \\
\hline \multicolumn{2}{|l|}{ Bare ground } \\
\hline Water & \\
\hline Roads & Highways, secondary, and service roads. \\
\hline Developed & $\begin{array}{l}\text { Human developed areas; includes urban, residential, and } \\
\text { commercial areas. }\end{array}$ \\
\hline Vegetation cover indices $\dagger$ & $\begin{array}{l}\text { Area-weighted vegetation cover indices calculated for each } \\
\text { stop landscape. }\end{array}$ \\
\hline \multicolumn{2}{|l|}{ Juniper tree cover index } \\
\hline \multicolumn{2}{|l|}{ Deciduous tree cover index } \\
\hline Total tree cover index & $\begin{array}{l}\text { Juniper and deciduous tree cover indices summed for each } \\
\text { stop landscape. }\end{array}$ \\
\hline \multicolumn{2}{|r|}{ deop tatuscape. } \\
\hline Herbaceous cover index & \\
\hline \multicolumn{2}{|l|}{ Landscape structure indices $\ddagger$} \\
\hline Mean patch size (ha) & Average size of all landscape patches. \\
\hline Mean core size (ha) & Average size of all core areas present in landscape. \\
\hline No. patches & Total number of landscape patches. \\
\hline Total edge $(\mathrm{m})$ & Total length of edge within landscape. \\
\hline Shannon's diversity index & $\begin{array}{l}\text { Measure of patch type diversity based on patch type number } \\
\text { and relative area of each patch type }\end{array}$ \\
\hline Shannon's evenness index & $\begin{array}{l}\text { Measure of patch type diversity relative to maximum pos- } \\
\text { sible diversity for a given number of patch types. }\end{array}$ \\
\hline Interspersion/juxtaposition index & $\begin{array}{l}\text { Observed over maximum patch type adjacencies or juxtapo- } \\
\text { sition for a given number of patch types. Ranges from a } \\
\text { maximum interspersion of } 100 \text { (all possible patch type } \\
\text { adjacencies) to } 0 \text { (no patch interspersion). }\end{array}$ \\
\hline \multicolumn{2}{|l|}{ Native grassland structure indices } \\
\hline Mean patch size (ha) & Average native grassland patch size. \\
\hline Mean core size (ha) & Average native grassland core area size. \\
\hline No. patches & Total number of native grassland patches in landscape. \\
\hline Interspersion/juxtaposition index & $\begin{array}{l}\text { Observed over maximum grassland patch adjacencies or jux- } \\
\text { taposition for total number of patch types present in land- } \\
\text { scape. Otherwise defined as above. }\end{array}$ \\
\hline
\end{tabular}

$\dagger$ See Methods for an explanation of calculations.

$\ddagger$ See McGarigal and Marks (1995) for the complete definition and calculation of each variable.

methods of trend determination such as route regression (Thomas 1996), in that many of the assumptions underlying linear models do not apply. The effects of high annual variation among counts are removed by the rankings, and the effects of autocorrelation among counts are minimized by using a short temporal span of data (Neter et al. 1985). We examined species population fluctuations for two time periods; 1965-1981 and 1981-1995. Species were arranged by habitat and nesting guild, and by migration type (DeGraaf et al. 1991, Peterjohn and Sauer 1993) to facilitate trend comparisons (see Table 2, which includes scientific names of all species noted in the text).

\section{Avian community data}

For comparison with changes in landscape cover and structure, we calculated the mean species abundance at each of the 50 stops on each route by averaging annual abundance across three disjunct time periods corresponding to the dates of aerial photography. This approach accounted for several limitations inherent in BBS data. Observer effects on data quality can be significant because of differences in observer ability and differing stop locations between observers (Sauer et al. 1994). We limited our use of count data to those with a high rating according to BBS criteria. All of the study routes that we selected for study were also surveyed 
by the same observer for at least two of three time periods, further reducing error sources (Sauer et al. 1994). In addition, Oklahoma is laid out in the township and range system, so stop locations are usually marked by quarter-section field boundaries and section-line roads and are very unlikely to have changed between observers. Finally, annual roadside abundance may vary substantially and independently of true population levels (Droege 1990). The use of mean annual abundance removes effects of both noise in annual counts and observers (Flather and Sauer 1996).

\section{Multivariate analysis}

To assess initial avian community differences among study areas and examine temporal shifts in community composition within study areas, bird community data were subjected to detrended correspondence analysis (DCA) with CANOCO version 4.0 (ter Braak and Smilauer 1998). By averaging sample scores produced by the DCA from each respective date and route $(n=50)$, we produced an ordination diagram of spatiotemporal trajectories that illustrates in ordination space the relative compositional dynamics of the avian community within and among the three study areas (Whisenant and Wagstaff 1991). We used correlation of DCA axis scores with landscape variables to identify gradients represented by the DCA ordination axes.

We related the avian community to landscape attributes using canonical correspondence analysis (CCA). CCA is a direct gradient analysis that constructs ordination axes that are linear combinations of the explanatory environmental or habitat variables (ter Braak 1987). We used a stepwise approach to select the best variables for model inclusion, and examined correlation coefficients and the variance inflation factor (VIF) produced by CANOCO to diagnose and prevent collinearity among environmental variables (ter Braak and Smilauer 1998). We assessed individual variables in the final model by calculating the intraset correlations (ter Braak 1986). This provides the correlation between a landscape variable and an axis, which is a measure of the relative importance of that particular variable to the axis.

The visual representation resulting from an ordination is a bi-plot (ter Braak 1986, Palmer 1993). Vectors in the bi-plot represent the correlation between a continuous explanatory variable and the CCA axes. Points representing categories of nominal explanatory variables are the centroids (the weighted averages) of that category (ter Braak 1986) and are also an approximation of the correlation between the explanatory variable and the axes. The position of a species point relative to a vector or a centroid indicates how strongly the species was associated with that particular variable. Because landscape vectors also extend in the opposite (negative) direction from the origin, a negative relationship between a species and variable can be indicated (Palmer 1993). The significance of the analysis relating the avian community to landscape attributes was tested by conducting Monte Carlo permutations on the bird-landscape relationship (ter Braak and Smilauer 1998). Because landscapes were adjacent locations on a linear transect, we used restricted permutations to remove the possible influence of spatial autocorrelation (Legendre 1993, ter Braak and Smilauer 1998).

\section{RESUlTS}

\section{Landscape dynamics}

Juniper and mixed-woodland cover types increased within landscapes in the Eagle City study area (Appendix A). This was concomitant with a decrease in deciduous woodland and shrubland cover types, as juniper apparently invaded and subsequently dominated many of these areas. Juniper cover and total tree cover increased accordingly within this study area. Agricultural grassland increased noticeably between 1981 and 1995. Only minor landscape structural changes occurred in this area, with patch size decreasing and patch number, total edge, and diversity increasing.

Juniper woodland and agricultural grassland also increased within Tegarden landscapes, as did indices of juniper and total tree cover (Appendix B). A notable decrease occurred in the amount of land in bare ground. Structural changes in this area were limited to slight increases in mean patch and core size and decreases in patch number and total edge. Grassland patch and core size also increased with a decrease in grassland patch number.

Juniper woodland was scarce in the Lookout study area, although mean juniper tree cover increased during the study period (Appendix C). Deciduous woodland, shrubland, agricultural grassland, deciduous tree cover, and total tree cover, however, increased within landscapes in this area. These were accompanied by decreases in cropland area, mean patch and grassland patch size and number, total edge, and patch interspersion/juxtaposition.

\section{Avian community dynamics}

A number of species showed significant $(P<0.1)$ population trends in the Eagle City study area from 1965 to 1981. American Crows, Common Grackles, and Yellow-billed Cuckoos increased, whereas Northern Cardinals and Northern Bobwhites declined (Table 2). The most substantial changes in this particular avian community occurred between 1981 and 1995, when 13 species had increasing population trends while only two were decreasing. Although four of the increasing species were grassland birds, the remaining species were open-habitat generalists or species associated with woody habitats.

Significant population trends in the Tegarden landscape were relatively sparse; there were no trends for any species from 1965 to 1981, and only American Crows and Northern Bobwhites increased from 1981 
TABLE 2. Species of the avian assemblage in three Oklahoma mixed-grass prairie landscapes.

\begin{tabular}{|c|c|c|c|c|c|c|c|}
\hline \multirow{4}{*}{$\begin{array}{c}\text { Habitat and nesting guild, }, \\
\text { migration type, and name }\end{array}$} & \multirow{4}{*}{ Acronym } & \multicolumn{6}{|c|}{ Route landscape } \\
\hline & & \multicolumn{2}{|c|}{ Eagle City } & \multicolumn{2}{|c|}{ Tegarden } & \multicolumn{2}{|c|}{ Lookout } \\
\hline & & \multicolumn{2}{|c|}{$\overline{1965-1981-}$} & \multirow{2}{*}{\multicolumn{2}{|c|}{$\begin{array}{cc}1965-1981- \\
1981 & 1995\end{array}$}} & \multicolumn{2}{|c|}{$1965-1981-$} \\
\hline & & & 1995 & & & & \\
\hline \multicolumn{8}{|l|}{ Grassland ground-nesting species } \\
\hline \multicolumn{8}{|l|}{ Permanent residents } \\
\hline $\begin{array}{l}\text { Ring-necked Pheasant } \\
\text { (Phasianus colchicus) }\end{array}$ & RNPH & & & & & + & \\
\hline $\begin{array}{l}\text { Eastern Meadowlark } \\
\text { (Sturnella magna) }\end{array}$ & EAML & & + & & & & \\
\hline $\begin{array}{l}\text { Western Meadowlark } \\
\text { (Sturnella neglecta) }\end{array}$ & WEML & & - & & - & & \\
\hline \multicolumn{8}{|l|}{ Temperate migrants } \\
\hline $\begin{array}{l}\text { Horned Lark } \\
\text { (Eremophila alpestris) }\end{array}$ & HOLA & & & & & - & \\
\hline $\begin{array}{l}\text { Cassin's Sparrow } \\
\text { (Aimophila cassinii) }\end{array}$ & CASP & & & & & & - \\
\hline $\begin{array}{l}\text { Grasshopper Sparrow } \\
\text { (Ammodramus savannarum) }\end{array}$ & GRSP & & + & & & & - \\
\hline \multicolumn{8}{|l|}{ Neotropical migrants } \\
\hline & $\mathrm{CONH}$ & & & & & + & - \\
\hline $\begin{array}{l}\text { Dickcissel } \\
\text { (Spiza americana) }\end{array}$ & DCSL & & + & & & + & \\
\hline \multicolumn{8}{|l|}{ Open habitat structure-nesting species } \\
\hline \multicolumn{8}{|c|}{ Permanent residents } \\
\hline $\begin{array}{l}\text { American Crow } \\
\text { (Corvus brachyrhynchos) }\end{array}$ & AMCR & + & + & & + & + & \\
\hline $\begin{array}{l}\text { Eastern Bluebird } \\
\text { (Sialia sialis) }\end{array}$ & EABB & & + & & & & \\
\hline $\begin{array}{l}\text { Northern Flicker } \\
\text { (Colaptes auratus) }\end{array}$ & NOFL & & & & & & \\
\hline \multicolumn{8}{|l|}{ Temperate migrants } \\
\hline $\begin{array}{l}\text { Loggerhead Shrike } \\
\text { (Lanius ludovicianus) }\end{array}$ & LHSH & & & & & & \\
\hline \multicolumn{8}{|l|}{ Neotropical migrants } \\
\hline $\begin{array}{l}\text { Scissor-tailed Flycatcher } \\
\text { (Tyrannus forficatus) }\end{array}$ & STFC & & & & - & - & \\
\hline $\begin{array}{l}\text { Cliff Swallow } \\
\text { (Hirundo pyrrhonota) }\end{array}$ & CLSW & & & & & + & - \\
\hline Mississippi Kite & MIKI & & & & - & & \\
\hline $\begin{array}{l}\text { (Ictinia mississippiensis) } \\
\text { Baltimore Oriole } \\
\text { (Icterus galbula) }\end{array}$ & BAOR & & - & & - & - & - \\
\hline \multicolumn{8}{|l|}{ Wetland and open water species } \\
\hline \multicolumn{8}{|l|}{ Temperate migrants } \\
\hline $\begin{array}{l}\text { Little Blue Heron } \\
\text { (Egretta caerulea) }\end{array}$ & LBHE & & + & & & & \\
\hline $\begin{array}{l}\text { Cattle Egret } \\
\text { (Bubulcus ibis) }\end{array}$ & CAEG & & + & & & & \\
\hline \multicolumn{8}{|l|}{ Successional scrub species } \\
\hline \multicolumn{8}{|l|}{ Permanent residents } \\
\hline $\begin{array}{l}\text { Northern Bobwhite } \\
\text { (Colinus virginianus) }\end{array}$ & NOBO & - & & & + & & \\
\hline $\begin{array}{l}\text { Northern Cardinal } \\
\text { (Cardinalis cardinalis) }\end{array}$ & NOCA & - & + & & & & \\
\hline \multicolumn{8}{|l|}{ Temperate migrants } \\
\hline $\begin{array}{l}\text { Bewick's Wren } \\
\text { (Thryomanes bewickii) }\end{array}$ & BEWR & & + & & & & \\
\hline $\begin{array}{l}\text { Brown Thrasher } \\
\text { (Toxostoma rufum) }\end{array}$ & BRTH & & & & & & \\
\hline $\begin{array}{l}\text { Field Sparrow } \\
\text { (Spizella pusilla) }\end{array}$ & FISP & & + & & & & \\
\hline $\begin{array}{l}\text { Lark Sparrow } \\
\text { (Chondestes grammacus) }\end{array}$ & LASP & & & & & - & \\
\hline $\begin{array}{l}\text { American Goldfinch } \\
\text { (Carduelis tristis) }\end{array}$ & AMGF & & & & & & \\
\hline
\end{tabular}


TABle 2. Continued.

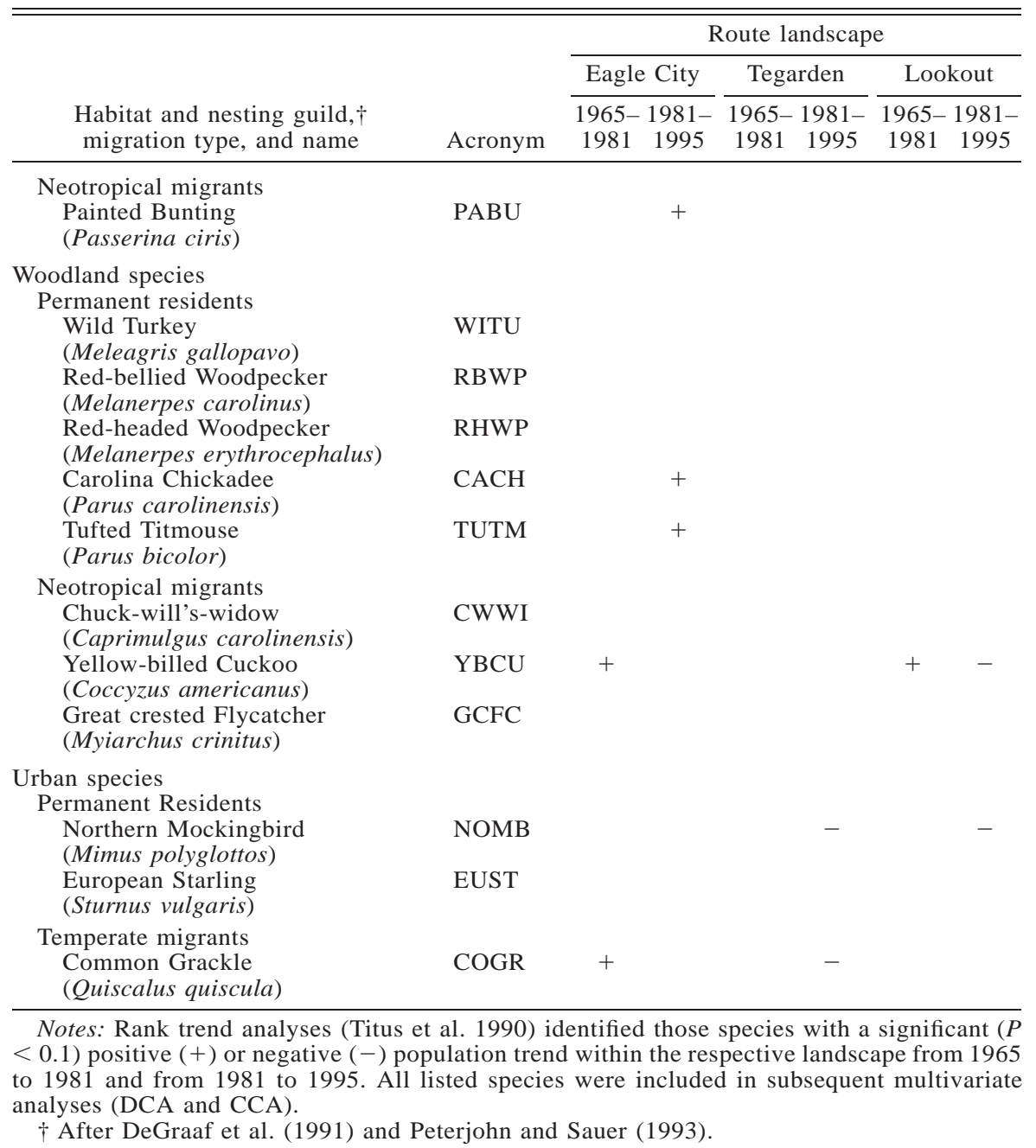

to 1995 (Table 2). However, Mississippi Kites, Baltimore Orioles, and Scissor-tailed Flycatchers, all neotropical migrants, and the Western Meadowlark, a grassland resident, decreased from 1981 to 1995.

Common Nighthawks, Cliff Swallows, and Yellowbilled Cuckoos increased in the Lookout area from 1965 to 1981 , but declined again from 1981 to 1995 (Table 2). Baltimore Orioles, Lark Sparrows, Scissortailed Flycatchers, and Horned Larks also declined from 1965 to 1981, whereas American Crows, Dickcissels, and Ring-necked Pheasants increased in abundance. Baltimore Orioles, Cassin's Sparrows, Grasshopper Sparrows, and Western Meadowlarks declined from 1981 to 1995 . No species was found to have a positive population trend within this landscape from 1981 to 1995.

Population and compositional changes resulted in significant variation in avian community trajectories both within and among study areas (Fig. 3). As seen from the relative position of annual means, avian communities within each study area were clearly distinct at the beginning of the study period, and remained so despite shifts in species abundance. Correlation analysis of DCA axis scores with landscape variables (Table 3) identified DCA axis one as a distinct gradient of vegetation type abundance (Fig. 3), which clearly separated each of the study areas and, especially for the Eagle City area, the 1995 centroid. Woody vegetation initially was more prevalent in the Eagle City area, which also experienced the most severe juniper encroachment. DCA axis 2 appeared to be a short gradient representing grassland structure (Fig. 3), as three structural measures were positively correlated with sample scores of this axis (Table 3 ). Thus, the three study areas appeared to separate along a chronosequence of landscape fragmentation based on grassland patch structure and the relative amounts of woody vegetation types (Fig. 3). 


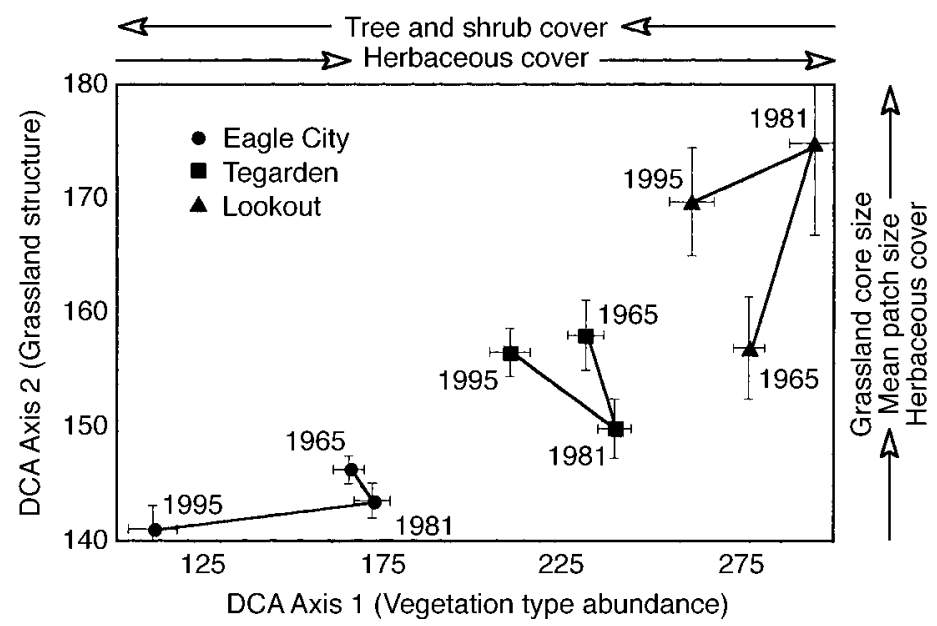

FIG. 3. DCA ordination bi-plot depicting relative avian community dynamics in the three study areas from 1965 to 1995 . Points on the trajectories represent mean sample scores $(n=$ 50) for the respective date and study area. Error bars indicate $\pm 1 \mathrm{SE}$

\section{Bird-landscape relationships}

Because of distinct differences in avian community dynamics and composition among the study areas (Fig. 3 ), we conducted separate CCA ordinations for each study area and included time as an explanatory variable. A distinct temporal gradient occurred along CCA axis one for the Eagle City area (Fig. 4), which was also weakly related to the increase in agricultural grassland and decrease in patch size (Table 4). Decreases in Western Meadowlarks, Baltimore Orioles, Loggerhead Shrikes, and Scissor-tailed Flycatchers from 1981 to 1995 mark a temporal shift in community structure. Similarly, large increases in Little Blue Herons and Cattle Egrets between 1981 and 1995 are reflected in their position near the 1995 centroid. The increase in these species is probably associated with the influx of woody vegetation suitable for the establishment of a nesting colony in or near the area.

CCA axis 2 was a landscape fragmentation gradient defined by tree cover and patch size. A number of woodland and shrubland birds showed a strong relationship with the total tree cover index, most notably the Carolina Chickadee and Tufted Titmouse. Three

TABLE 3. Results of correlation analyses of DCA axis-1 and axis-2 scores with landscape variables from all study landscapes collectively.

\begin{tabular}{lcc}
\hline \hline \multirow{2}{*}{$\begin{array}{c}\text { Landscape variables } \\
\text { correlated with DCA axes }\end{array}$} & \multicolumn{2}{c}{ Correlation coefficient, $r$} \\
\cline { 2 - 3 } & DCA 1 & DCA 2 \\
\hline Total tree cover index & $-\mathbf{0 . 4 4 1 2} * * *$ & $-0.1600 * * *$ \\
Shrub cover index & $-\mathbf{0 . 2 3 9 2} * * *$ & -0.0319 \\
Herbaceous cover index & $\mathbf{0 . 2 8 4 4} * * *$ & $\mathbf{0 . 1 6 6 9} * * *$ \\
Mean patch size & $0.1402 * *$ & $\mathbf{0 . 1 8 4 3} * * *$ \\
Mean grassland core size & $0.2218 * * *$ & $\mathbf{0 . 1 8 5 6} * * *$ \\
\hline
\end{tabular}

Notes: Only the three variables most strongly correlated with DCA sample scores are presented. Boldface coefficients $(r)$ are for those variables that were most strongly correlated with the respective axis.

$* * P<0.01 ; * * * P<0.001$. grassland birds, the Eastern Meadowlark, Grasshopper Sparrow, and Dickcissel, were all associated with an increase in agricultural grassland and were oriented nearest this short vector (Fig. 4). The first two CCA axes accounted for $19 \%$ of the total variance in the species data, and $83 \%$ of the extracted variance in the species-environment relationship. The Monte Carlo test of the relationship found that both the first CCA axis $(F=23.6 ; P=0.005)$ and the overall analysis $(F$ $=8.52 ; P=0.005)$ were significant.

A complex avian community-landscape relationship was found in the Tegarden area. A structural gradient ranging from bare ground, herbaceous cover, shrubland to tree cover was indicated by CCA axis one (Table 4). A number of species oriented accordingly along this gradient, including Scissor-tailed Flycatchers and Common Nighthawks with bare ground; Western Meadowlarks with herbaceous cover; and Yellowbilled Cuckoos, American Crows, Northern Cardinals, Mississippi Kites, and Great-crested Flycatchers near shrubland and tree cover index vectors (Fig. 5). Axis 2 represented a temporal gradient marking significant population changes for several species within this landscape (Table 2). The first two CCA axes accounted for $11 \%$ of the total variance in the species data and $60 \%$ of the extracted variance in the species-environment relationship. The Monte Carlo test of the relationship found that both the first CCA axis $(F=9.11 ; P=$ $0.005)$ and the overall analysis $(F=4.37 ; P=0.005)$ were significant.

A major temporal gradient defined CCA axis one in the Lookout area (Table 4). This secondarily represented a landscape structure gradient including changes in mean core size and the number of native grassland patches (Fig. 6). Most notable was the orientation of several grassland and neotropical migrant species near the patch core size vector. Axis 2 was also predominantly a temporal axis, but secondarily indicated a fragmentation gradient defined by the number of native 
FIG. 4. Ordination bi-plot depicting the first two axes of the CCA illustrating bird-landscape relationships for the Eagle City study area. Continuous landscape variables are represented by vectors, date centroids by filled squares, and species locations by their acronyms from $\mathrm{Ta}$ ble 2 .

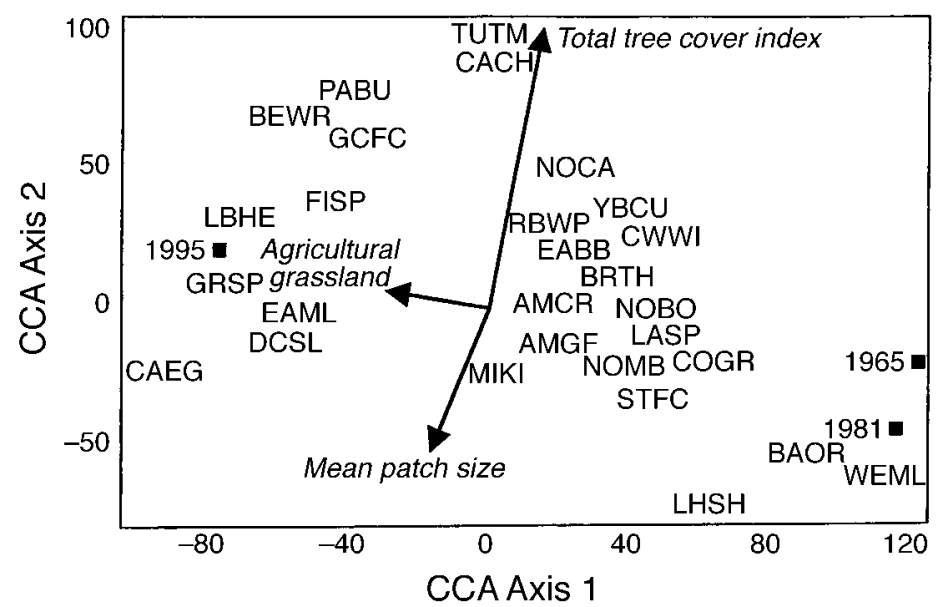

grassland patches and the amount of deciduous woodland. European Starlings oriented near the number of native grassland patches, whereas several woodland and successional scrub species, including Yellow-billed Cuckoos, Ring-necked Pheasants, American Crows, and Northern Flickers, oriented nearest the deciduous woodland vector (Fig. 6). The first two CCA axes accounted for $11 \%$ of the total variance in the species data and $68 \%$ of the extracted variance in the speciesenvironment relationship. The Monte Carlo test of the relationship found that both the first $\mathrm{CCA}$ axis $(F=$

TABLE 4. Intraset correlations between landscape variables and CCA axes 1 and 2 for the Eagle City, Tegarden, and Lookout study areas.

\begin{tabular}{lrr}
\hline \hline & \multicolumn{2}{c}{ Correlation coefficient, $r$} \\
\cline { 2 - 3 } Variable, by study area & CCA 1 & \multicolumn{1}{c}{ CCA 2} \\
\hline Eagle City & & \\
1965 & $\mathbf{0 . 6 0 1}$ & -0.101 \\
1981 & 0.570 & -0.220 \\
1995 & $-\mathbf{0 . 9 5 4}$ & 0.261 \\
Total tree cover index & 0.139 & $\mathbf{0 . 9 8 8}$ \\
Percentage agricultural & -0.121 & 0.122 \\
grassland & & \\
Mean patch size & -0.157 & $-\mathbf{0 . 4 6 0}$ \\
Tegarden & & \\
1965 & -0.472 & $-\mathbf{0 . 6 3 0}$ \\
1981 & 0.119 & $\mathbf{0 . 7 5 2}$ \\
1995 & 0.445 & -0.036 \\
Total tree cover index & $\mathbf{0 . 6 2 1}$ & 0.250 \\
Herbaceous cover index & -0.199 & -0.064 \\
Percentage shrubland & 0.398 & 0.020 \\
Percentage cropland & 0.029 & -0.214 \\
Percentage bare ground & $-\mathbf{0 . 4 7 8}$ & 0.396 \\
Lookout & & \\
1965 & $\mathbf{0 . 8 1 6}$ & $-\mathbf{0 . 3 6 1}$ \\
1981 & $-\mathbf{0 . 7 8 5}$ & -0.256 \\
1995 & 0.040 & $\mathbf{0 . 7 1 7}$ \\
Deciduous woodland & -0.312 & 0.469 \\
Mean core size & 0.482 & 0.101 \\
No. native grassland & -0.351 & -0.361 \\
patches & & \\
\hline
\end{tabular}

Note: Boldface values are for those variables most positively and negatively associated with each axis in the respective analysis.
11.2; $P=0.005)$ and the overall analysis $(F=5.33$; $P=0.005)$ were significant.

\section{Discussion}

\section{Species response to habitat structure}

Native grassland area and landscape pattern, especially grassland patch size, were adversely affected by woody encroachment. However, a number of neotropical migrants with woody habitat requirements either had positive population trends in areas affected by woody encroachment or were positioned nearest woody vegetation gradients in multivariate analyses. This suggests that some of these species may benefit from increasing woody vegetation in Great Plains grasslands, an important possibility, considering that many populations of birds that use woody habitats and migrate to the neotropics are rapidly declining (Robbins et al. 1989, Peterjohn and Sauer 1994).

Similarly, a number of temperate migrants and resident species associated with woody vegetation or classified as open-habitat generalists also increased from 1981 to 1995. These included Cattle Egrets, Eastern Bluebirds, Carolina Chickadees, Tufted Titmice, Bewick's Wrens, Northern Cardinals, Field Sparrows, and American Crows, most of which also oriented along woody vegetation gradients. In contrast, a number of grassland birds exhibited either declining populations or negative association with woody vegetation gradients. Populations of Western Meadowlarks consistently declined across study areas, and this species was absent in surveys from the Eagle City area in the late 1980s. Most grassland birds had at least one negative population trend, and most were negatively positioned with respect to woody vegetation gradients.

\section{Landscape pattern and avian community structure}

Landscape pattern indices were important in both the most (Eagle City) and least (Lookout) fragmented landscapes, whereas vegetation and cover type composition were most important in the area of moderate encroach- 


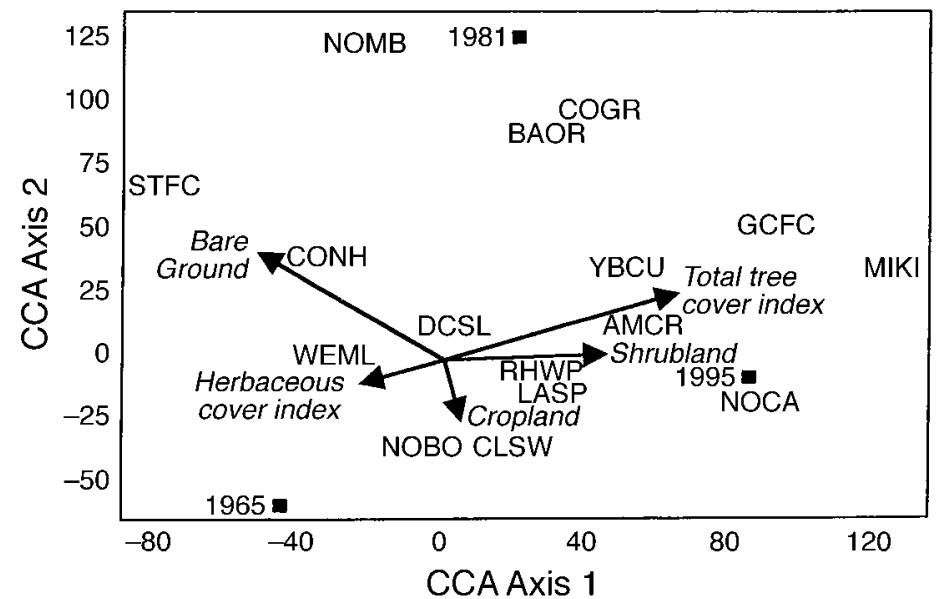

FIG. 5. Ordination bi-plot depicting the first two axes of the CCA illustrating bird-landscape relationships for the Tegarden study area. Continuous landscape variables are represented by vectors, date centroids by filled squares, and species locations by their acronyms from $\mathrm{Ta}$ ble 2 . ment (Tegarden). Area and patch size are important determinants of habitat suitability for grassland birds (Herkert 1994, Helzer and Jelinski 1999), and although we limited our study to a single spatial scale by choosing the BBS survey as a data source, we found that landscape structural changes did affect grassland bird abundance at our scale of study. The disappearance of Western Meadowlarks from the area most affected by juniper suggests that rapid structural changes resulting from woody plant invasion made this area unacceptable for this species. Helzer and Jelinski (1999) recently demonstrated that the occurrence of Western Meadowlarks was strongly influenced by grassland patch area. A related study has demonstrated that an increase in woody vegetation in grasslands is strongly correlated with changes in measures of overall landscape pattern that are indicative of fragmentation (B. R. Coppedge, S. D. Fuhlendorf, D. M. Engle, R. E. Masters, and M. S. Gregory, unpublished manuscript). Many grassland species were affiliated with the core size vector in the Lookout area bi-plot, including Horned Lark, Cassin's Sparrow, Lark Sparrow, Eastern Meadowlark, and
Western Meadowlark. Because this study area was predominantly native grassland (Appendix C), these results suggest that patches in this area, which were least affected by woody encroachment, remained suitable for area-sensitive grassland birds. This was probably due to the presence of large interior or core areas of grassland habitat free of woody vegetation.

The importance of landscape structure to the avian community in both the most and least fragmented study areas also suggests that two fragmentation thresholds may exist for birds inhabiting Oklahoma grasslands. The first threshold is near the $60 \%$ native grassland composition exhibited in the Lookout study area, a value that is consistent with percolation theory and habitat connectivity models (Gardner et al. 1987, Loehle et al. 1996). The other threshold appears to be near the 30$40 \%$ native grassland composition, as found in the Eagle City study area. This value is consistent with the hypothesis offered by Andren (1994), who found that as suitable habitat approaches $30 \%$ of the landscape, patch size and interpatch distance begin to affect ani-

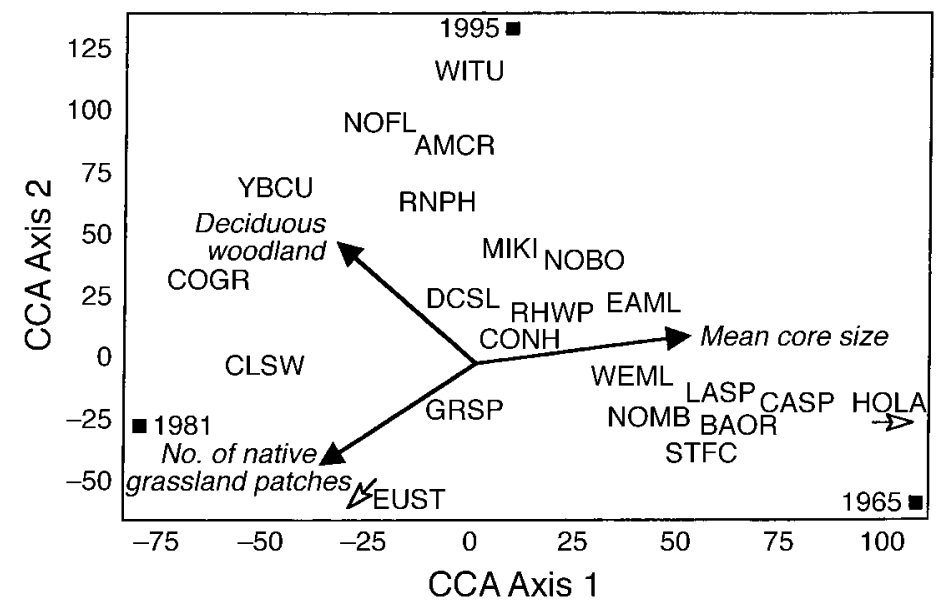

FIG. 6. Ordination bi-plot depicting the first two axes of the CCA illustrating bird-landscape relationships for the Lookout study area. Continuous landscape variables are represented by vectors, date centroids by solid squares, and species locations by their acronyms from Table 2. Open arrows indicate the approximate direction and location of species points that were outside the scale of the plot. 
mal populations more noticeably than does the total habitat area alone.

\section{Effects of woody vegetation}

Our data suggest that total grassland area and patch size are not the only important influences on grassland birds. The composition and structure of patch vegetation appear to exert equal importance in structuring the avian community. An influx of woody vegetation generally increases the resource base for the avian community, but in turn alters composition by attracting avian exotics and habitat generalists and decreasing habitat suitability for endemic and obligate avian species (Blair 1996, Farina 1997, Preiss et al. 1997). The limited resource base inherent to North American grasslands because of recurrent drought is one of the primary ecological limitations on the size and diversity of grassland bird communities (Wiens 1974a, b). In fact, the Great Plains once served as a geographic barrier to woodland avifaunas (Mengel 1970), but westward expansion of species from eastern deciduous forests has been fostered by the development of riparian woodlands along major rivers (Johnson 1994) that provide a habitat corridor across the Great Plains (Knopf 1986). The mixing of regional avifaunas that has resulted is responsible for the loss of several subspecific avian forms and a tremendous loss of genetic and community distinctiveness (Rising 1983, Knopf 1986). Because nest predators and nest parasites increase near woody habitat edges (Johnson and Temple 1990), the addition of juniper woodland patches in grassland landscapes may only serve to magnify existing problems of avifaunal mixing because of habitat homogenization (Knopf 1992). Our results directly support earlier assertions that prevention of grassland degradation by woody vegetation would contribute significantly to the recovery of grassland bird populations (Herkert 1994). Even partial restoration of historic factors controlling the distribution of woody vegetation in Great Plains grassland would seem warranted. Such factors might include prescribed fire (Bragg and Hulbert 1976) and the destruction of woody plants that results from the presence of native grazers such as bison Bison bison L. (Coppedge and Shaw 1997). Limited applications of modern methods of brush control such as chaining or cutting could also help to curb the advance of juniper, thereby imparting both ecological and economic benefits to southern plains grasslands (Engle et al. 1995).

\section{CRP grasslands: source or sink habitat?}

Despite the fact that much of the vegetation on CRP areas in the southern Great Plains consists of monocultures of non-native grasses (Newman 1988), some grasslands birds benefit from these areas (Johnson and Schwartz 1993, Herkert 1997, 1998). Increased abundance of Dickcissels, Grasshopper Sparrows, Field Sparrows, and Eastern Meadowlarks in our Eagle City study area appears to be linked to the creation of ag- ricultural grasslands by the CRP by the late 1980s. Although these species are known to use CRP grasslands (Best et al. 1997, Herkert 1998), it is worth noting that a similar response in abundance was not seen in the other study areas where these grasslands also increased. Instead, agricultural grasslands were a significant habitat variable only in the area most affected by encroaching juniper, an area that also had the least amount of intact native grassland. Thus, CRP benefits to breeding birds may simply be relevant to, and dependent on, the context of the surrounding landscape. These bird species probably are using the most structurally suitable grasslands available in this particular landscape.

Studies comparing CRP fields to cultivated cropland have concluded that CRP fields are better avian nesting and breeding habitat because of the disturbances inherent to cropland (Johnson and Igl 1995, Patterson and Best 1996, Best et al. 1997). However, there are no studies comparing avian success on native grasslands relative to exotic grass monocultures, so it is unknown whether CRP grasslands function as population sources or sinks relative to native prairie (Pulliam and Danielson 1991). The BBS data used for this study provide a measure of the relative abundance of breeding birds, which is an indication of nesting preference, but BBS data do not provide information on nesting success for the various habitat types. Furthermore, the suitability of CRP grasslands for birds relative to native prairie invaded and fragmented by woody vegetation is unknown. These comparisons need immediate research attention, especially in view of the rate of woody plant encroachment in Great Plains grasslands (Archer 1994), and the likelihood that many CRP grasslands will revert to cropland in the near future (Soil and Water Conservation Society 1994).

\section{Conclusions}

Although we found instances of increasing abundance of some neotropical migrants in study areas experiencing woody plant invasion of fragmented grasslands, we also found many examples of decreasing grassland species. The benefits of CRP grasslands are dependent on landscape context, because grassland birds responded to CRP in the area most affected by juniper invasion, but they did not respond where native grassland remained fairly abundant and structurally sound. Thus, CRP grasslands may have the potential to provide suitable grassland habitat where little or no native prairie exists. But it also appears that CRP benefits are temporary. We suggest that increased focus on grassland habitat management and continuation of agricultural set-aside programs be concentrated in areas where grasslands have been severely altered by woody vegetation encroachment or heavily fragmented by agricultural activity. 


\section{ACKNOWLEDGMENTS}

This work was supported by the USDA National Research Initiative Competitive Grants Program (grant number 9600853) and the Oklahoma Agricultural Experiment Station. We thank Bruce Peterjohn for providing us with raw BBS data, Daniel Shorter and Paul Nighswonger for sharing their knowledge of the BBS routes used for this study, and all of the volunteers who annually conduct the BBS. We also thank Thomas Gavin, Fritz Knopf, Kevin McGarigal, Terrence Bidwell, and Samuel Fuhlendorf for helpful comments on an earlier manuscript draft. This article is published with the approval of the director, Oklahoma Agricultural Experiment Station.

\section{Literature Cited}

Andren, H. 1994. Effects of habitat fragmentation on birds and mammals in landscapes with different proportions of suitable habitat: a review. Oikos 71:355-366.

Archer, S. 1994. Woody plant expansion into southwestern grasslands and savannahs: rates, patterns, and proximate causes. Pages 13-68 in M. Vavra, W. Laycock, and R. Pieper, editors. Ecological implications of livestock herbivory in the West. Society for Range Management, Denver, Colorado, USA.

Askins, R. A. 1993. Population trends in grassland, shrubland, and forest birds in eastern North America. Current Ornithology 11:1-34.

Atkinson, K. L. 1985. Nursery production and distribution of eastern redcedar and its perception. Pages 17-25 in R. F. Wittwer and D. M. Engle, editors. Eastern Redcedar in Oklahoma Conference Proceedings. Oklahoma State University, Oklahoma Cooperative Extension Service Circular E-849. Stillwater, Oklahoma, USA.

Axelrod, D. I. 1985. Rise of the grassland biome, central North America. Botanical Review 51:163-202.

Best, L. B., H. Campa III, K. E. Kemp, R. J. Robel, M. R. Ryan, J. A. Savidge, H. P. Weeks, Jr., and S. R. Winterstein 1997. Bird abundance and nesting in CRP fields and cropland in the Midwest: a regional approach. Wildlife Society Bulletin 25:864-877.

Blair, R. B. 1996. Land use and avian species diversity along an urban gradient. Ecological Applications 6:506-519.

Bragg, T. B., and L. C. Hulbert. 1976. Woody plant invasion of unburned Kansas bluestem prairie. Journal of Range Management 29:19-24.

Brown, J. R., and S. Archer. 1989. Woody plant invasion of grasslands: establishment of honey mesquite (Prosopis glandulosa var. glandulosa) on sites differing in herbaceous biomass and grazing history. Oecologia 80:19-26.

Brown, J. R., and J. Carter. 1998. Spatial and temporal patterns of exotic shrub invasion in an Australian tropical grassland. Landscape Ecology 13:93-102.

Bystrak, D. 1981. The North American Breeding Bird Survey. Studies in Avian Biology 6:34-41.

Coppedge, B. R., and J. H. Shaw. 1997. Effects of horning and rubbing behavior by bison (Bison bison) on woody vegetation in a tallgrass prairie landscape. American Midland Naturalist 138:189-196.

Daubenmire, R. 1959. A canopy-coverage method of vegetational analysis. Northwest Science 33:43-64.

Davidson, C. 1998. Issues in measuring landscape fragmentation. Wildlife Society Bulletin 26:32-37.

DeGraaf, R. M., V. E. Scott, R. H. Hamre, L. Ernst, and S. H. Anderson. 1991. Forest and rangeland birds of the United States: Natural history and habitat use. U.S. Department of Agriculture, Agricultural Handbook AH-688.

Droege, S. 1990. The North American Breeding Bird Survey. Pages 1-4 in J. R. Sauer and S. Droege, editors. Survey designs and statistical methods for the estimation of avian population trends. U.S. Fish and Wildlife Service Biological Report 90(1).

Dunn, C. P., D. M. Sharpe, G. R. Guntenspergen, F. Stearns, and Z. Yang. 1991. Methods for analyzing temporal changes in landscape pattern. Pages 173-198 in M. G. Turner and R. H. Gardner, editors. Quantitative methods in landscape ecology. Springer-Verlag, New York, New York, USA.

Engle, D. M., T. G. Bidwell, and M. E. Moseley. 1995. Invasion of Oklahoma rangelands and forests by eastern redcedar and ashe juniper. Oklahoma State University, Oklahoma Cooperative Extension Service Circular E-947. Stillwater, Oklahoma, USA.

Farina, A. 1997. Landscape structure and breeding bird distribution in a sub-Mediterranean agro-ecosystem. Landscape Ecology 12:365-378.

Flather, C. H., and J. R. Sauer. 1996. Using landscape ecology to test hypotheses about large-scale abundance patterns in migratory birds. Ecology 77:28-35.

Gardner, R. H., B. T. Milne, M. G. Turner, and R. V. O'Neill. 1987. Neutral models for the analysis of broad scale landscape patterns. Landscape Ecology 1:19-27.

Gustafson, E. J. 1998. Quantifying landscape spatial pattern: what is the state of the art? Ecosystems 1:143-156.

Hansen, A. J., and D. L. Urban. 1992. Avian response to landscape pattern: the role of species life history. Landscape Ecology 7:163-180.

Helzer, C. J., and D. E. Jelinski. 1999. The relative importance of patch area and perimeter-area ratio to grassland breeding birds. Ecological Applications 9:1448-1458.

Herkert, J. R. 1994. The effects of habitat fragmentation on midwestern grassland bird communities. Ecological Applications 4:461-471.

Herkert, J. R. 1997. Population trends of the Henslow's Sparrow in relation to the Conservation Reserve Program in Illinois, 1975-1995. Journal of Field Ornithology 68:235244.

Herkert, J. R. 1998. The influence of the CRP on Grasshopper Sparrow population trends in the mid-continental United States. Wildlife Society Bulletin 26:227-231.

Johnson, D. H., and L. D. Igl. 1995. Contributions of the Conservation Reserve Program to populations of breeding birds in North Dakota. Wilson Bulletin 107:709-718.

Johnson, D. H., and M. D. Schwartz. 1993. The Conservation Reserve Program and grassland birds. Conservation Biology 7:934-937.

Johnson, R. G., and S. A. Temple. 1990. Nest predation and brood parasitism of tallgrass prairie birds. Journal of Wildlife Management 54:106-111.

Johnson, W. C. 1994. Woodland expansion in the Platte River, Nebraska: patterns and causes. Ecological Monographs 64: 45-84.

Knopf, F. L. 1986. Changing landscapes and the cosmopolitanism of the eastern Colorado avifauna. Wildlife Society Bulletin 14:132-142.

Knopf, F. L. 1992. Faunal mixing, faunal integrity, and the biopolitical template for diversity conservation. Transactions of the 57th North America Wildlife and Natural Resources Conference 57:330-342.

Knopf, F. L. 1994. Avian assemblages on altered grasslands. Studies in Avian Biology 15:247-257.

Legendre, P. 1993. Spatial autocorrelation: trouble or new paradigm? Ecology 74:1659-1673.

Loehle, C., B. L. Li, and R. C. Sundell. 1996. Forest spread and phase transitions at forest-prairie ecotones in Kansas, U.S.A. Landscape Ecology 11:225-235.

McGarigal, K., and B. J. Marks. 1995. FRAGSTATS: spatial pattern analysis program for quantifying landscape structure. U.S. Forest Service General Technical Report PNW 351 . 
McGarigal, K., and W. C. McComb. 1995. Relationships between landscape structure and breeding birds in the Oregon Coastal Range. Ecological Monographs 65:235-260.

Mengel, R. M. 1970. The North American central plains as an isolating agent in bird speciation. Pages 280-340 in W. Dort and J. K. Jones, Jr., editors. Pleistocene and recent environments of the central Great Plains. University of Kansas Press, Lawrence, Kansas, USA.

Neter, J., W. Wasserman, and M. H. Kutner. 1985. Applied linear statistical models. Richard D. Irwin, Homewood, Illinois, USA.

Newman, J. B. 1988. Overview of the present land-use situation and the anticipated ecological impacts of program implementation. Pages 55-59 in J. E. Mitchell, editor. Impacts of the Conservation Reserve Program in the Great Plains. U.S. Forest Service Rocky Mountain Forest and Range Experiment Station General Technical Report RM158.

Palmer, M. W. 1993. Putting things in even better order: the advantages of canonical correspondence analysis. Ecology 74:2215-2230.

Patterson, M. P., and L. B. Best. 1996. Bird abundance and nesting success in Iowa CRP fields: the importance of vegetation structure and composition. American Midland Naturalist 135:153-167.

Pearson, S. M. 1993. The spatial extent and relative influence of landscape-level factors on wintering bird populations Landscape Ecology 8:3-18.

Peterjohn, B. G., and J. R. Sauer. 1993. North American Breeding Bird Survey annual summary 1990-1991. Bird Populations 1:52-67.

Peterjohn, B. G., and J. R. Sauer. 1994. Population trends of woodland birds from the Breeding Bird Survey. Wildlife Society Bulletin 22:155-164.

Polley, H. W., H. B. Johnson, and H. S. Mayes. 1994. Increasing $\mathrm{CO}_{2}$ : comparative responses of the $\mathrm{C}_{4}$ grass $\mathrm{Schi}$ zachyrium and grassland invader Prosopis. Ecology 75 976-988.

Preiss, E., J. Martin, and M. Debussche. 1997. Rural depopulation and recent landscape changes in a Mediterranean region: consequences to the breeding avifauna. Landscape Ecology 12:51-61.

Pulliam. H. R., and B. J. Danielson. 1991. Sources, sinks, and habitat selection: a landscape perspective on population dynamics. American Naturalist 137:50-66.

Rising, J. D. 1983. The Great Plains hybrid zones. Current Ornithology 1:131-157.

Robbins, C. S., D. K. Dawson, and B. A. Dowell. 1989. Habitat area requirements of breeding forest birds of the middle Atlantic states. Wildlife Monograph 103:1-34.

Robinson, G. R., R. D. Holt, M. S. Gaines, S. P. Hamburg, M. L. Johnson, H. S. Fitch, and E. A. Martinko. 1992.
Diverse and contrasting effects of habitat fragmentation. Science 257:524-526.

Saab, V. 1999. Importance of spatial scale to habitat use by breeding birds in riparian forests: a hierarchical analysis. Ecological Applications 9:135-151.

Samson, F., and F. Knopf. 1994. Prairie conservation in North America. BioScience 44:418-421.

Sauer, J. R., B. G. Peterjohn, and W. A. Link. 1994. Observer differences in the North American Breeding Bird Survey. Auk 111:50-62.

Saunders, D. A., R. J. Hobbs, and C. R. Margules. 1991. Biological consequences of ecosystem fragmentation: a review. Conservation Biology 5:18-32.

Soil and Water Conservation Society. 1994. When Conservation Reserve Program contracts expire: the policy options. SWCS, Ankeny, Iowa, USA.

ter Braak, C. J. F. 1986. Canonical correspondence analysis: a new eigenvector technique for multivariate direct gradient analysis. Ecology 67:1167-1179.

ter Braak, C. J. F. 1987. The analysis of vegetation-environment relationships by canonical correspondence analysis. Vegetatio 69:69-77.

ter Braak, C. J. F., and P. Smilauer. 1998. CANOCO reference manual and user's guide to CANOCO for Windows: Software for canonical community ordination (version 4). Microcomputer Power, Ithaca, New York, USA.

Thomas, L. 1996. Monitoring long-term population change: why are there so many analysis methods? Ecology 77:49_ 58

Titus, K., M. R. Fuller, and D. Jacobs. 1990. Detecting trends in hawk migration count data. Pages 105-113 in J. R. Sauer and S. Droege, editors. Survey designs and statistical methods for the estimation of avian population trends. U.S. Fish and Wildlife Service Biological Report 90(1).

Whisenant, S. G., and F. J. Wagstaff. 1991. Successional trajectories of a grazed salt desert shrubland. Vegetatio 94: 133-140.

Wiens, J. A. 1974a. Climatic instability and the ecological saturation of bird communities in North American grasslands. Condor 76:385-400.

Wiens, J. A. 1974b. Habitat heterogeneity and avian community structure in North American grasslands. American Midland Naturalist 91:195-213.

Wiens, J. A., and J. T. Rotenberry. 1981. Habitat associations and community structure of birds in shrubsteppe environments. Ecological Monographs 51:21-41.

Wiens, J. A., J. T. Rotenberry, and B. Van Horne. 1987. Habitat occupancy patterns of North American shrubsteppe birds: the effects of spatial scale. Oikos 48:132-147.

Young, E. C., and C. T. Osborn. 1990. Costs and benefits of the Conservation Reserve Program. Journal of Soil and Water Conservation 45:370-373.

\section{APPENDIX A}

A table presenting summary statistics for landscape variables in the Eagle City study area is available in ESA's Electronic Data Archive: Ecological Archives A011-002-A1.

\section{APPENDIX B}

A table presenting summary statistics for landscape variables in the Tegarden study area is available in ESA's Electronic Data Archive: Ecological Archives A011-002-A2.

\section{APPENDIX C}

A table presenting summary statistics for landscape variables in the Lookout study area is available in ESA's Electronic Data Archive: Ecological Archives A011-002-A3. 